\title{
The Determinants of Domestic Private Investment in Nigeria
}

\author{
${ }^{1}$ Atoyebi Kehinde .O., ${ }^{2}$ Adekunjo Felix .O., ${ }^{3}$ Kadiri Kayode .I., ${ }^{4}$ Falana Adedamola .A. \\ ${ }^{1,2,3,4}$ Lagos State University, Ojo Dept. Of Economics.
}

\begin{abstract}
This study empirically examines the pattern of domestic investment during the period under consideration. The study runs from 1970 through 2010. Being a time series data, to avoid spurious regression results. The first step was to test for the stationarity of the data by using Philip - Peron unit root test. Then Johansen (1988) technique was used to established if the non-stationary variable are cointegrated. The result of stationarity and normality test reveals that the model is fairly well specified and could be used for policy analysis. Empirical investigations showed that growth in private investment are best explained by changes in political situation as represented by a dummy variable representing investment climate. The overall measure of macroeconomic instability and political situation serves as an hindrance to private investment. We recommended that there should be a change in the objectives and focus on private sector participation by increasing domestic credit to this sector and as well creating an enabling environment via the provision infrastructural facilities and security.
\end{abstract}

Keywords: Domestic Private Investment, macroeconomic instability, investment climate, private sector. Paper Type: Research Paper

A large body of literature has discussed extensively on the analysis of the determinants of investment for several decades. The analysis has been conducted at several levels of aggregation at the firm level, the industry level and the economy. The early theoretical and empirical studies could not find universal applicability because, macro economic conditions with a country has become a dynamic phenomenon.

The worldwide shift towards a growth strategy emphasizing market forces and private sector led, in many countries, to a reduction of the public sector from production and also redefining its role in development process, under the guiding principle that the public sector should devote its resources in areas where it supports, rather than replacing the activity of the private sector.

It is generally believed that the long term economic growth of a country will lead to a significant improvement in the standard of living of its citizens, thus, a sustainable increase in domestic private investment will go along way to reduce wide spread poverty in Nigeria, as a result of its impact on economic growth.

A closer look at the pattern of domestic investment in Nigeria becomes imperative inorder to achieve desirable macroeconomic objectives - over the years, high macro economic volatility has become a key determinant of poor economic management overall, the economy has been characterized by low savings investment equibriumatives $20 \%$ growth rate.

With an average annual investment rate of barely $16 \%$ of GDP, Nigeria is too far behind the minimum investment rate of about $30 \%$ of GDP to unleash a poverty reducing economic growth rate of about $7.8 \%$ per annum.

Generally, the performance of the economy has been largely influenced by integration of monetary, fiscal and exchange rate policy.

These polices also has been a determinant factor for the growth of private sector in the economy and subsequent investment patterns.

\section{Introduction}

The main motivation of the paper came from a study carried out on another country (Malaysia) Guimaraes and Unteroberdoerster (2006), investigated similar issues with datas from Malaysia and found that there is an evidence for a stable long-run relationship between real output growth and investment. The study also find out the impact of real growth on investment positive and highly significant in the long-run indicating that one percent increase in real growth will bring about on the average 2 to $4 \%$ higher investment.

Undoubtedly despite the structural reform carried out by Nigeria government, Nigeria is still saddled with a number of economic Maladies. Among these problems are low level of savings and investment, high rate of inflation, wide spread poverty and highly level of unemployment. These situation as increase so many researchers who have described the reforms woes rather than a blessing. Instead for the economy to adjust into recovery, the situation continuing to deteriorate. The expected role of private sector as an engine of growth never materialized. The major expansion in private investment needed to sustain economic growth is yet to be achieved. The macroeconomic indicators in Nigeria reflect these poor performance between 1970 through 2008. For example, private investment declined from $32.2 \%$ before 1970 to $6.5 \%$ in 1976 . The ratio also declined to 
$5.8 \%$ in 1995 but experienced an increase to $8.3 \%$ in 2003 and also resulted to a decline to $6.3 \%$ in 2008 . The perceptible slide in the ratio of private sector investment to GDP despite the emphasis on private sector following the initiation of public sector reform is worrisome.

In the light of this background, our researcher findings are quite different from the earlier studies.

This is because three of the variables examined are statistically significant and the variables are percentage distribution of public investment which is significant at 10\%, external reserve which is statistically significant at $1 \%$ and gross domestic product that is statistically significant at $10 \%$.

The findings on public investment contradict the earlier studies that there is a "crowding out" effect of public investment on private "domestic" investment in Nigeria rather suggest "crowding in" effect of public investment over private domestic investment in Nigeria. The external reserve result suggest that a unit increase in external reserve will bring about on the average $2 \%$ increase in domestic private investment in Nigeria which is actually consistent with the similar result obtained by Chibber and Manssoor (1990) the case of Mexico.

Conclusively, the GDP result suggest that a unit increase in gross domestic product will produce on the average about $22.6 \%$ increase in domestic private investment which is inconsistent with the one of obtained in the case of cote d'Ivoire (kouassy and Bohoun, 1992).

The objective of this study is to analyses the trends in domestic investment in the context of Nigeria economy and also determine the macro economic policy variables which could influence domestic private investment and estimate econometrically the model which links investment and macro-economic policy variables The rest of the study is structured as follows: section 2 presents the trends in domestic private investment in Nigeria. Section 3 presents review of literature. Section 4 presents data source and description as well as empirical analysis section 5 concludes the study.

\section{Public And Private Investment In Nigeria:An Overview}

The trend in aggregate domestic investments in Nigeria has been erratic over the years since independence. In general, the performance of domestic investment is weak. After independence, investment as a share of GDP rose from about $10.7 \%$ in 1960 to $18.3 \%$ in 1995 representing a growth rate of about $11 \%$ with in the period. After the civil war and with the advert of the petroleum oil, gross domestic investment performed better. Gross domestic fixed capital formation rose from 16.9 percent in 1970 to 32.2 percent in 1976. The ratio has declined since then to 6.5 percent in 1976. This also declined to $6.5 \%$ in 1984 and 5.8 percent in 1995 in between there are occasional improvements as in 1991 and 1997 when the ratio was 11.0 and 11.7 percent respectively. Consider table 1.1 which is derived from Obadan and Odusola, 2001, page 33.

Nigeria GDP growth rate (\%), Gross fixed capital formation (GCF) \% share of GDP and Gross fixed capital formation (Growth rate as \% share of GDP (1970-2010).

Table 1

\begin{tabular}{|c|c|c|c|}
\hline Real GDP Growth Rate & GCF (\%) & $\begin{array}{lll}\text { GCF } & (\%) \text { Share of } \\
\text { GDP } & & \end{array}$ & Growth Rate of GDP/GDP ratio \\
\hline 1970 & - & 16.9 & - \\
\hline 1971 & 21.3 & 19.4 & 0.0 \\
\hline 1972 & 5.5 & 23.8 & 22.7 \\
\hline 1973 & 6.4 & 17.3 & -27.3 \\
\hline 1974 & 11.7 & 26.3 & 52.0 \\
\hline 1975 & -3.0 & 32.2 & 52.2 \\
\hline 1976 & 11.1 & 32.2 & \\
\hline 1977 & 8.2 & 28.9 & 52.2 \\
\hline 1978 & -7.4 & 28.6 & -10.2 \\
\hline 1979 & 2.4 & 22.8 & -10.0 \\
\hline 1980 & 4.1 & 23.3 & -2.0 .4 \\
\hline 1981 & -2.6 & 25.7 & 2.2 \\
\hline 1982 & -0.3 & 22.0 & 10.3 \\
\hline 1983 & -5.4 & 12.1 & -14.4 \\
\hline 1984 & -5.1 & 6.5 & -45.0 \\
\hline 1985 & 5.9 & 7.3 & 46.3 \\
\hline 1986 & 2.2 & 10.7 & 12.3 \\
\hline 1987 & -0.3 & 9.0 & 46.6 \\
\hline 1988 & 7.0 & 6.6 & -16.9 \\
\hline 1989 & 7.3 & 5.7 & -26.7 \\
\hline 1990 & 8.2 & 8.8 & -13.6 \\
\hline 1991 & 4.8 & 11.0 & 54.4 \\
\hline 1992 & 3.0 & 10.7 & 25.0 \\
\hline
\end{tabular}


The Determinants Of Domestic Private Investment In Nigeria

\begin{tabular}{|l|l|l|l|}
\hline 1993 & 2.1 & 11.6 & -2.7 \\
1994 & 1.3 & 9.3 & 8.4 \\
1995 & 2.2 & 5.8 & -19.8 \\
1996 & 3.4 & 5.8 & -37.6 \\
1997 & 3.2 & 10.0 & 72.4 \\
1998 & 2.4 & 9.9 & -1.0 \\
1999 & 1.1 & 9.8 & 1.0 \\
2000 & 3.8 & 9.2 & 7.0 \\
2001 & 3.5 & & 6.4 \\
2002 & 3.0 & 9.0 & 6.0 \\
2003 & 7.1 & 8.3 & 6.0 \\
2004 & 6.2 & & 10.0 \\
2005 & 6.9 & 5.5 & 5.0 \\
2006 & 5.3 & 6.0 & 6.0 \\
2007 & 6.4 & & 7.0 \\
2008 & 5.3 & 6.3 & 6.0 \\
2009 & 5.6 & & \\
2010 & 8.4 & & \\
\hline
\end{tabular}

Source: CBN Statistical Bulleting, 2008

As the table reveals, there was an appreciable growth in investment during the oil boom era as goes capital formation as a ratio of GDP rose from 23.8 percent in 1973 to 32.2 percent in 1976, when the oil revenue dwindled in 1978/79 the rate declined to 25.7 percent. The decline in growth rate capital formation followed a declare in GDP within the same period. During this period, GDP growth rate recorded negative values. The investment GDP ratio has remained how since the early 1980s. The post SAP periods did not received any appreciable rose in the rate of capital formation. The figures from table 1.1 show a decline following marginal rise in the growth rate of capital formation in 1986.

The ratio of growth rate capital formation to GDP was 10.7 percent, which declined to 5.7 percent in 1989. It record a marginal increase in 1993 before declining again to 5.8 percent in 1996. GDP growth rate during the period remained low and declining from the year 2000, there have been fluctuation in the growth of capital formation due to poor investment climate.

\section{Review of Literature}

The contribution of domestic private investment to the economy has been debated extensively over the years. These debate covers both the developed and underdeveloped economies. However, a lot more has been put into the study of domestic investment since it seems that a sustainable domestic private investment will reduce widespread poverty in the economy.

In developing country like Nigeria, private investment is also playing prominent role. Khan and Khan (2001) attempted to analyse the determinants of private investment by using ARDL cointegration technique to check the existence of long run equilibrium relationship as well as short run dynamics of investment. The results supported the idea of providing suitable environment for markets e.g protection of policy rights, enforcement of contracts and voluntary exchange at market determined prices.

The model of attempt to review the trend of foreign capital flows to Nigeria and compared with those of other developing countries in Asia Ataullah etal (2002) reviews the trend of foreign private investment. For these, trends of all the variable are collected from the 1970-2000 was taken from the global development of domestic institutional structure, human capital and indigenous entrepreneurship.

Ahmed and Asghar (2004) analysed household saving with respect to the characteristics of households. The study made use of saving function by using dummy variables approach and concluded that saving behaviour is influenced by various factors including wealth, employment status education age, dependency.

In a study by Herwatz and Fang (2006) on the role of private investment in OECD countries, EU and euro areas. The cross section data collected were from 1971-2002. The study concluded that the country dependent savinginvestment model is the best performing model.

Joshi (2007) made an attempt to categories domestic saving capital account of the balance of payments as explanatory variables for capital formation in the country. The long run steady state relationship between various component of saving capital account balance and gross domestic capital formation is estimated. He however, conclude that inflow increase capital formation and growth in the economy. And, that there is long run relationship between saving and capital account with capital formation.

Also, the study by Wahid etal (2008) in South Asia. Panel data were used for five South Asia countries over the period 1973-2012. The study finds the existence of low positive correlation between savings and investment in threes selected Asian countries. 
In a paper written by Guimaraes and Unteroberdoester (2006), the relationship between real output, growth and investment is analysed particularly in Malaysia after an unprecedented in the wake of the Asian crises. The study found out the impact of real growth on investment is positive and highly significant in the long run indicating that a $1 \%$ increase in real growth will bring about on the average 2 to $4 \%$ increase investment. Apart from growth, a dummy variable is used for Asian crises which is a proxy for uncertainty) which is found to be statistically significant, though the coefficient is negative in all specification. The results do not clearly support that capital cost that is measured by average real banking lending rates) has a negative short run impacts on the growth of private investment.

Erden and Hocokombe (2005) have examined the impact of public investment on private investment. They applied several pooled specifications of a standard investment model to a panel of developing economies from the period 1980 to 1997 . Their study find out that public investment crowds in private investment i.e. an average, a $10 \%$ increase in public investment is associated with $2 \%$ increase in private investment.

Moreover, the results also indicate that in developing economies availability of bank credit is the major constraint for private investment.

Everhart and sumlisk (2001) analyzed the quality of public investments its interactive with corruption and the resulting impact on private investment for 63 developing countries from 1970 to 2000 . They found out that lagged private investment and the availability of credit to private sector are positive and significant. The external debt is also negative with expected negative sign implying that the presence of large external debt burden implies uncertainty.

The results also confirm that higher public investment is associated with a lower private investment which further leads to an increase in private investment.

Bazoumana (2004) analyzed the determinants of private investment in general. He found a significant relationship between private investment and its explanatory variables. Public infrastructure investment was found to be positively related with private investment GDP, credit to the private sectors and terms of trade has a significant negative impact in private investment.

Bayraktar and Fofak (2007) derive a formal specification of a private investment function in SubSaharan Africa. Using the Tobin's Q theory and the neo-classical theory of investment, their results point to the significant role played by aggregate profitability shock, and by financing of investment in determining the level of private investment in Africa.

Ariyo and Raheem's (1991) country estimation of the determinants of investment consisted of public investment rate of growth of GDP, domestic credit to the private sector and interest rate as arguments in the private investment function. "Their results show that all variables were statistically significant and evidence of the existence of crowding in".

Against this background, it is necessary to investigate further other macroeconomic and financial variables that have been affecting domestic investment in a typical developing country context.

Most relevant to this study is the analysis in Asante (1993), which estimates private investment equation by trying to assess the determinants of domestic private investment in Ghana. Following the ideas in Asante (1993), this study investigates the macroeconomic determinants of domestic investment in Nigeria over the period 19702008.

\section{Data Set}

\section{Method Of Research}

The data used in this study is mainly acquired of Federal Bureau Statistics (FBS Nigeria) and also from the Central Bank Statistical bulletin Annual abstracts (2008). This collected data of the variables formed the basis of our calculating the studies covered thirthy eight financial year time period from 1970-2008.

\section{$\underline{\text { Sample }}$}

The sample of the study is taken from different economic determinants highlighted from previous studies. There are two basic factors that could influence private investment namely: Economic and Non economic factors. Economic factors are used in this studies because they are most influential variables of the private investment. The sample range of the study is based on the availability of data. The 1970 data is chosen because that marked the oil boom era in Nigeria and 2008 data is chosen because that marked the end of the first phase of reform i.e National Economic empowerment development strategy that was introduced in 2003 by the Apex bank..

4.1 In this section, different hypothesis of interest in the study are discussed with intent to determine whether a relationship that is supported by literature holds true in our research.

Hypothesis 1.

H11: There is no significant relationship between annual interest rate and domestic private investment. 
The study assumes that annual interest rate has a negative impact On domestic private investment. This implies that the higher the rate of interest the lower would be the stimulus to invest.

\section{Hypothesis 2:}

H21: Domestic credit to the private sector has a positive impact on domestic private investment.

Hypothesis 3:

H31: That deposit ratio has a positive impact on domestic on private investment.

\section{Hypothesis 4:}

H41. External reserves has a positive impact an domestic private investment.

\section{Hypothesis 5:}

H51: That nominal exchange rate has a negative impact on domestic private investment.

\section{Hypothesis 6:}

H61: That public investment will have a posture impact investment.

\subsection{MODEL SPECIFICATION AND EMPIRICAL RESULTS}

We use Ordinary Least Square (OLS) method to examine the relationship between gross domestic investment, AI,DCS,DR,ER,GDI,GDP,NE,PI

In order to determine the impact of these variables on the gross domestic investment, the multiple regression equation is explicitly specified in functional form as follows:

$\mathrm{GDI}=\mathrm{f}(\mathrm{AI}, \mathrm{DCS}, \mathrm{DR}, \mathrm{ER}, \mathrm{GDP}, \mathrm{NE}, \mathrm{PI})$.

Where GDI= dependent variable, which is Gross Domestic Investment

\section{Definition of terms}

$\mathrm{AI}=$ Annual interest rate

DCS $=$ Domestic credit to the private sector

$\mathrm{DR}=$ Deposit ratio

$\mathrm{ER}=$ External reserve

GDP $=$ Gross domestic product

$\mathrm{NE}=$ Nominal exchange rate

$\mathrm{PI}=$ Public investment

This can be specifically expressed in explicit econometric form as:

$G D I=\alpha_{0}+\alpha_{1} A I+\alpha_{2} D C S+\alpha_{3} D R+\alpha_{4} E R+\alpha_{5} G D P+\alpha_{7} P I+U_{t}$

Where $U$-stochastic or random error term (with usual properties of zero mean and non-serial correlation).

$\alpha_{1-} \alpha_{8}=$ Co-efficient of associated variables

$\alpha_{0}=$ Constant Intercept.

\section{Data Analysis and findings}

Model 1: OLS, Using observations 1970-2008 ( $\mathrm{T}=40)$

Table 1 - OLS Regression Analysis Results

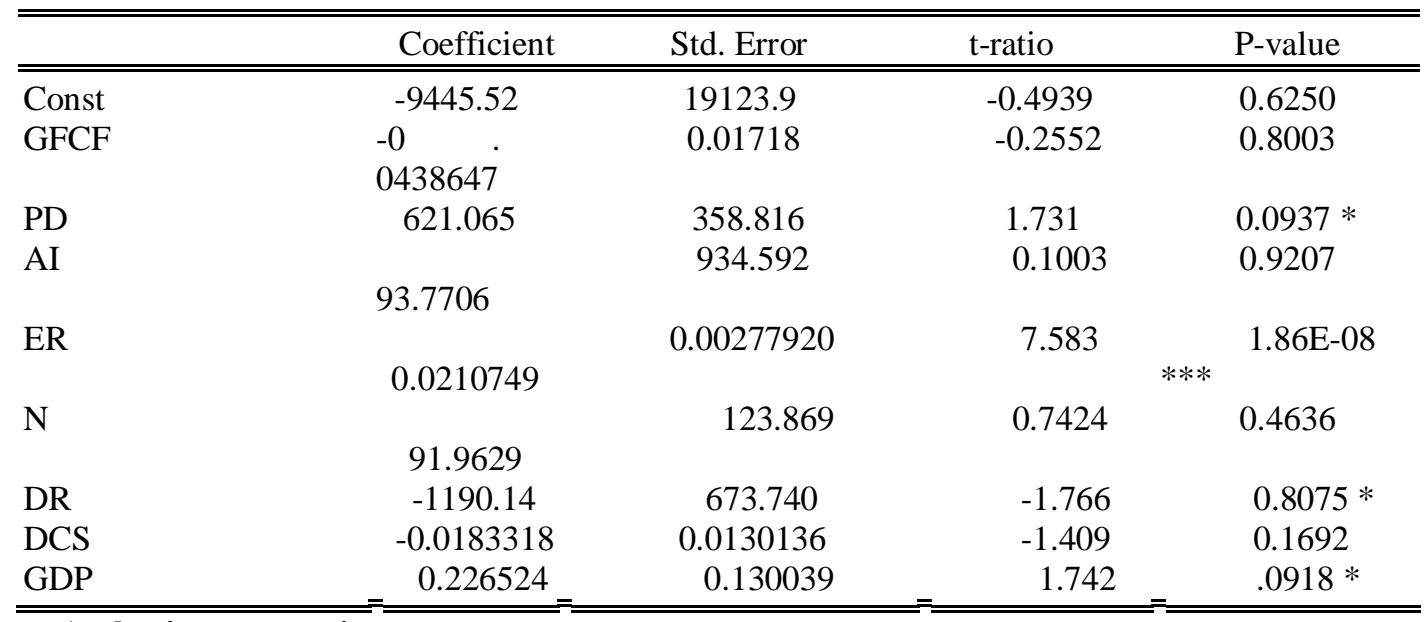

Source: Author's computation

Note: $* * *=$ significant at $1 \% ; * *=$ significant at $5 \%$ and $*=$ significant at $10 \%$ 
The Determinants Of Domestic Private Investment In Nigeria

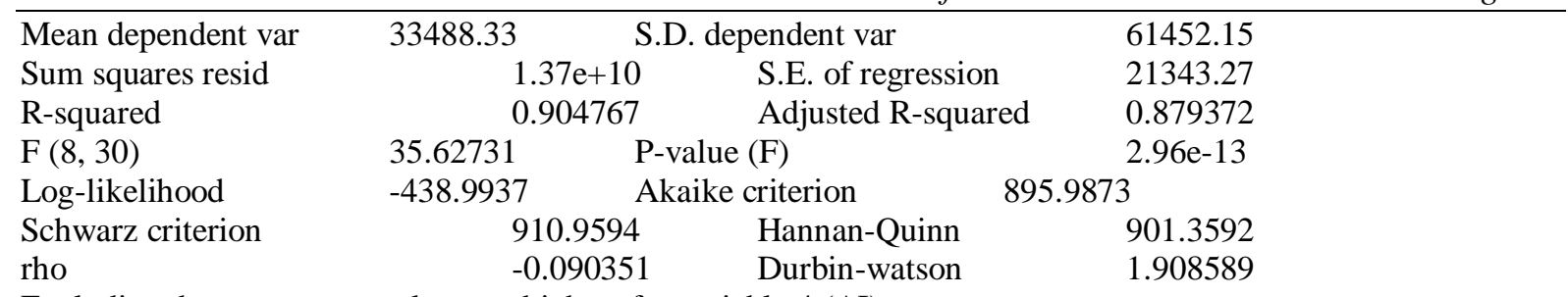

Excluding the constant, p-value was highest for variable 4 (AI)

The result of the estimation of regression summarized in the table above are analysed based on the priori expectation of the magnitudes of the variables examined for instance the nominal exchange rate is expected to have a positive impact on private investment. Our result clearly support this expectation. The sign of the annual interest rate does not support this expectation. Theoretically, interest rate is expected to be negatively related to investment i.e the higher the rate of interest the lower the stimuli to invest which is in accordance with Keynesian theory of investment. As far as the coefficient of domestic credit to private sector is concerned, it shows the negative sign but insignificant effect on private investment. It implies that if there is an increase in domestic credit to the private sector it will reduce private investment. But as the variable is insignificant, so our result do not support significantly on empirical ground. On the other hand a change in bank credit does not have any significantly favourable effect on the private investment. This sterns on the fact that the available credit to the private sector are misused by private investors. Moreover, the facility of credit does not only matter but the cost of financing cannot be ignored. So the result implies a direct role of monetary policy in influencing private investment behaviour. Since, monetary policy in Nigeria has been implemented through the use of credit rationing. For such type of polices to work, financial markets must be kept segmented and restricted.

The estimated coefficient of GDP to private investment is positive and significant. It support the hypothesis of Guimaraes and Unterobordoerster (2006) that the increase in GDP due to an increase in FDI could produce an accelerator effect on domestic investment. Thus, a one unit increase in GDP will bring about a $22 \%$ increase in domestic investment.

The R-squared which is the coefficient of determination, shows the percentage of variation in the dependent variable that was accounted for by variations in the explanatory variables. It measures the explanatory powers of the model. It is usually between zero and one. A close inspection of the table above indicates that the specified model has a fairly high coefficient of determination. This can be seen from Rsquared of 90 per cent. The R-squared reports that the variables can explain about 90 per cent of total variation in gross domestic investment the remaining 10 per cent variation in the gross domestic investment are not accounted for in the model or rather accounted for by other variables outside the model. The fitness of every regression result is based on its $\mathrm{R}$-squared. The adjusted R-squared shows that asymptotically, the variables can explain approximately 88 per cent of total variation. The implication of this is that the model has goodness of fit.

F-statistics test the overall significance of the model under study. F-calculated is compared with Ftabulated where F- cal is greater than F-tab we reject the null hypothesis (Ho) and conclude that the variable is statistically significant in explaining the dependent variable. From the table, it shows that F-statistics is 35.62731 and Prob (F-statistic) 0.000000 we therefore reject null hypothesis and accept alternative hypothesis. This is because it is greater than the critical values of 2.57 and 3.79 at $1 \%$ and $5 \%$ respectively. Thus, it implies that the model is statistically significantly different from zero. In other words, the explanatory variables jointly considered are significantly important in explaining variation in the dependent variable -gross domestic investment.

Durbin - Watson Statistic indicates whether there is serial correlation in the model. If there is serial correlation in the model it therefore implies that the model has lost its predictive power. Durbin - Watson Statistic is given as 1.908589 and this suggests that the model is free autocorrelation. Consequently, the estimated model can be confidently relied upon for making inferences and for prediction purposes.

Summarily, our model incorporate a new variable as deposit ratio which was not included in the previous studies. But, we found out that though the coefficient is statistically significant at $10 \%$ but negatively related to domestic private investment. The results suggest that a unit increase in deposit ratio will bring about on the average $1,190 \%$ reduction in domestic private investment which is in consistent with the empirical evidence.

\section{Unit Root Test Result}

Literature has established that most time series variables are not stationary. Therefore, using nonstationary variables in the model might lead to spurious regression which cannot be used for precise prediction. (Gujarati, 2003). Hence, our first step is to examine the characteristics of the time series data used for estimation of the model to determine whether the variables have unit roots, that is, whether it is stationary and the order of integration. The Augmented Dickey-Fuller test is used for this purpose. A variable is considered stationary if the 
The Determinants Of Domestic Private Investment In Nigeria absolute ADF value is higher than any of the absolute Mackinnon values. The test is conducted with intercept term.

Table 2: Unit Root Test Summary Statistics (Augmented Dickey Fuller)

\begin{tabular}{|l|l|l|l|l|l||}
\hline \multirow{2}{*}{ Variables } & \multicolumn{2}{|c|}{ ADF Test Statistics } & \multicolumn{2}{c|}{ Critical Values (5\%) } & $\begin{array}{l}\text { Order of } \\
\text { Integration }\end{array}$ \\
\cline { 2 - 6 } & Level & $1^{\text {st }}$ Difference & Level & $1^{\text {st }}$ Difference & \\
\hline AI & -1.457647 & -9.587272 & -2.943427 & -2.943427 & $\mathrm{I}(1)$ \\
\hline DCS & -0.171923 & -8.365949 & -2.945842 & -2.945842 & $\mathrm{I}(1)$ \\
\hline DR & -1.599624 & -5.147705 & -2.943427 & -2.948404 & $\mathrm{I}(1)$ \\
\hline ER & -0.651281 & -8.529741 & -2.941145 & -2.943427 & $\mathrm{I}(1)$ \\
\hline GDP & -2.030665 & -13.60087 & -2.943427 & -2.945842 & $\mathrm{I}(1)$ \\
\hline NE & -1.514859 & -4.410176 & -2.943427 & -2.943427 & $\mathrm{I}(1)$ \\
\hline PD & -2.416782 & -4.623664 & -2.941145 & -2.943427 & $\mathrm{I}(1)$ \\
\hline PI & -1.249447 & -4.574797 & -2.945842 & -2.948404 & $\mathrm{I}(1)$ \\
\hline GDI & 1.118714 & -3.011807 & -2.986225 & -2.991878 & $\mathrm{I}(0)$ \\
\hline
\end{tabular}

Source: Author's computation

From the table above the results clearly showed that all the variables are non-stationary at level. This suggests the need to difference the series to obtain stationarity. At first difference, however all the variables are integrated of the same order, cointegration analysis is justified.

Table 3:

Johanse test:

Number of equations $=9$

Lag order $=1$

Estimation period: $1971-2008(\mathrm{~T}=38)$

Case 3: Unrestricted constant

\begin{tabular}{|l|l|l|l|l|l|}
\hline Rank & Eigenvalue & Trace test & p-value & Lmax test & p-value \\
\hline 0 & 0.99074 & 403.17 & $(0.0000)$ & 177.93 & $(0.0000)$ \\
\hline 1 & 0.89721 & 225.23 & $(0.0000)$ & 86.453 & $(0.0000)$ \\
\hline 2 & 0.72075 & 138.78 & $(0.0054)$ & 48.475 & $(0.0239)$ \\
\hline 3 & 0.56178 & 90.303 & $(0.1105)$ & 31.352 & $(0.3527)$ \\
\hline 4 & 0.48172 & 58.952 & $(0.2703)$ & 24.975 & $(0.3994)$ \\
\hline 5 & 0.35655 & 33.976 & $(0.5078)$ & 16.754 & $(0.6097)$ \\
\hline 6 & 0.23600 & 17.222 & $(0.6323)$ & 10.229 & $(0.7270)$ \\
\hline 7 & 0.11029 & 6.9930 & $(0.5846)$ & 4.4407 & $(0.8066)$ \\
\hline 8 & 0.064959 & 2.5522 & $(0.1101)$ & 2.5522 & $(0.1100)$ \\
\hline & eigenvalue & 0.99074 & 0.89721 & 0.72075 & 0.56178 \\
\hline & 0.48172 & 0.236000 .3565 & 0.11029 & 0.064959 & \\
\hline
\end{tabular}

The summary of the results in table 3 where $r$ takes two possible values are due to the fact that lambdamax and trace test gave different test results. The test $r=2$ would imply that both series are stationary, but the unit root and trend stationarity test conducted on the single series indicate that they are unit root processes.

Cointegration analysis is justified since the components of a vector time series process have a unit root and the $Z_{t}$ is a multivariate $I(I)$ process which signifies existence of a linear combination $\beta^{\mathrm{T}} \mathrm{Z}_{\mathrm{t}}$ which may be interpreted as long term relationship between those variables.

The likelihood ratio test for binding restriction is $\mathrm{LR}=403.17$ and this is the probability of committing type 1 error in the parentheses.

This test refer to both long run and the above loading matrix restriction. 
The Determinants Of Domestic Private Investment In Nigeria

Table 4: Granger causality tests

\begin{tabular}{|c|c|c|c|}
\hline $\begin{array}{c}\text { Depende } \\
\text { nt } \\
\text { Variable }\end{array}$ & Testing Hypothesis & F1 & $\mathbf{F 2}$ \\
\hline \multirow{8}{*}{ GDI } & GDP there is a unidirectional relationship(GDP $\Leftarrow$ GDI) & 37.4566 & 0.55808 \\
\hline & NE there is no causality (GDI $\neq N E$ ) & 0.18482 & 0.66685 \\
\hline & PD there is no causality (GDI $\neq \mathrm{PD})$ & 0.44222 & 0.26537 \\
\hline & PI there is a unidirectional relationship $(\mathrm{GDI} \Leftarrow \mathrm{PI})$ & 11.5979 & 1.82127 \\
\hline & ER there is a unidirectional relationship(GDI $\Rightarrow \mathrm{ER})$ & 10.8847 & 0.79794 \\
\hline & DR there is no causality (GDI $\neq D R$ ) & 1.17933 & 0.07052 \\
\hline & DCS there is a unidirectional relationship $($ GDI $\Leftarrow$ DCS $)$ & 0.23382 & 11.9288 \\
\hline & AI there is no causality (GDI $\neq \mathrm{AI})$ & 0.19896 & 0.17329 \\
\hline
\end{tabular}

Source: Author's computation

From table 4 above we can infer that: there is a unidirectional causal relationship between the gross domestic investment and GDP with direction from gross domestic investment to GDP, unidirectional causal relationship between the gross domestic investment and PI with direction from PI to gross domestic investment, there is a unidirectional causal relationship between the gross domestic investment and ER with direction from gross domestic investment to ER and final a unidirectional causal relationship between the gross domestic investment and DCS with direction from DCS to gross domestic investment. Also, there is no causal relationship between the gross domestic investment and NE, between gross domestic investment and PD, between gross domestic investment and DR, and between gross domestic investment and AI.

\section{Conclusion}

This study has been attempted to examine the economic factors which affect private investment significantly and which can be used as policy variables to get the desired results for capital formation and determining the investment behaviour in Nigeria and to determine the relationship between public and private investment.

The empirical analysis based on the time series data for Nigeria over the period 1970-2008. Most of the data have been collected from Federal Bureau of statistics and statistical Bulletin of Central Bank of Nigeria Annual Abstracts and various issues of Economic survey. All the regression equations are estimated by the ordinary least square technique. The results for this study provide some support for the hypothesis that the rates or private investment are affected by important macro-economic variables. The econometric tests undertaken support he view that private sector output, Gross domestic product, credit to the private sector have all been significant determinants of private investment rates. The empirical evidence suggests that if the sector lack adequate credit then there will be a reduction in the level of private investment with adverse effect on the longterm productive capacity of the private sector. The introduction of a very important variable i.e annual interest rate. The results suggest that interest rate is inversely related to private investment but it is significant. This is consistence with the empirical evidence that when interest rate rises, cost of borrowing increases so, there will be a decline in future profits. As a result, the stimulus to invest is discouraged. The result provide evidence that private investment in Nigeria is constrained by availability of financing, and that monetary policy, and that monetary policy, could be used to influence private investment decision. In order to attract the private investment, a country must formulate and implement suitable polices. The proper use of bank credit as a policy instrument can actually influence the level of private investment in Nigeria. With regards to fiscal policy, public investment is expected to play a prominent role in boosting up the level of private investment. But the result obtained is contrary to the expectation; however, there should still be provision for proper physical, technological and financial infrastructure by the government.

In addition, cost of financing i.e interest rate is expected to be low because it will induce private investors to invest. Therefore, government should reduce the borrowing and lending charges.

Finally, the government is also advised to create a conducive environment that will attract domestic and foreign investor. It would also be beneficial to increase the capacity of local firms to respond to new investment opportunities and to expand business relationship with foreign investors. 


\section{References}

[1] Abbas V, 2004 'What Determines Private Investment in Iran', International Journal of Social Economics vol. 31.

[2] Abdul Rashid. 2006, 'Public - Private Investment linkage in Pakistan', South - Asia Economic Journal, vol. 7, 219.

[3] Ahmed, M. \& Ahmed, Q 2002, 'Foreign Capital inflows and domestic saving in Pakistan, Cointegration technique and error correction modeling, the Pakistan', Development Review 41 (4), pp. 825-836.

[4] Asghar, T. \& Ahmed, M. 2004, 'Estimation of saving behavior', The Lahore Journal of Economics, vol. 9, no. 2.

[5] Atukeren, E. 2005, 'Interactions between Public and Private Investment', Evidence form Developing Countries, KY KLOS, 58 (3), pp. 307-330.

[6] Bazoumana .O. 2004, 'Modeling the long term Determinants of Private Investment in Senegal', Credit research paper, University of Nottingham.

[7] Blejer, M.I. \& M.S. Khan 2001, 'Government Policy and Private Investment in Developing Countries', IMF Staff Papers, 31 (2), pp. 379-403.

[8] Erden, L. \& Randall G. Holcombe 2005, 'The Effects of Public Investment on Private Investment in Developing Economies' Public Finance Review, 33 (5), pp. 575-602.

[9] Everhart S. \& M.A. Sum linski 2001, 'Trends in Private Investment in Developing Countries', Statistics for 1970-2000 and the Impact of Private Investment on Corruption and the Quality of Public Investment, World Bank, IFC Discussion Paper no.44.

[10] Festus Tangeni 2007, 'Impact of Public and Private Investment on Economic growth', African Journal of Economic Development and Growth.

[11] Guimaraes, R. \& Olaf Unteroberdoerster 2006, 'What's driving private investment in Malaysia? Aggregate trends and firm-level evidence', IMF Working paper 06/190/.

[12] Herwartz, H. \& Xu, F. 2006, 'What determines the relation between domestic saving and Investment a new look at the puzzle'. Institute for Statistics and Economics, Christian Albrecht's University of Kiel, pp. 40-60.

[13] Joshi, H. 2007, 'The role of domestic saving and Foreign Capital flows in Capital Formation in India', Reserve Bank of India, Occasional Paper 28 (3).

[14] Khan, S. \& Arshad, M. 2001, 'What determines Private Investment', A case of Pakistan, The Pakistan Institute of Development Economics, working paper no. 36.

[15] Le, M \& Ataullah, A. 2002, 'Foreign Capital and Economic performance of Pakistan', The Lahore Journal of Economics.

[16] Naqvi, Naveed H. 2002, 'Crowding-in or crowding-out? Modeling the relationship between Public and Private Fixed Capital Formation using Co-integration Analysis, the case of Pakistan 1964-2000', Pakistan Development Review, 41 (3), pp. $225-267$.

[17] Nasir, S. \& Khalid, M. 2004, 'Saving investment behaviour in Pakistan, An empirical investigation', The Pakistan Development Reviews 43 (4), pp. 665-682.

[18] Pargal S. 2003, 'Regulation and Private Sector Investment in Infrastructure', Evidence from Latin America, World Bank Policy Research Working Paper 3037.

[19] Sasaki, K. \& M.T. Yousaf Khan 2001, 'Roles of Public Capital in Pakistan's Economy, Productivity, Investment and Growth Analysis', RURDS, 13(2), pp. 143-162.

[20] Shahbaz, M. Awan, R. \& Ali, L. 2008, 'Bi-directional causality between FDI and saving', A case of Pakistan, International Research Journal of Finance and Economics, Issue 17.

[21] Taylor, A. 2003, 'Domestic saving and International capital flows Reconsidered', Department of Economics, North western university, United States.

[22] Wahid, A, Salahuddin, M. \& Noman, A. 2008, 'Saving Investment Correlation in South Asia. A panel approach', European Journal of Economics and Administrative Sciences, Issue 11. 